\title{
The association of codon 392 polymorphism in ESR2 gene with breast cancer in Iran
}

\author{
Sakineh Abbasi \\ Department of Medical Laboratory Sciences \\ School of Allied Medical Sciences \\ Tehran University of Medical Sciences \\ Tehran, Iran \\ abbasisk@tums.ac.ir
}

\author{
Samira Kalbasi \\ Department small pets \\ Faculty of Veterinary Medicine \\ University of Tehran \\ Tehran, Iran \\ samira_kalbasi@yahoo.com
}

Volume $4-$ Special
Issue: 3rd International
Conference on Health \&
Medical
Insight into Aciences:
Medical
(ICHMS 2019)

DOI:

10.24017/science.2019

.ICHMS.26

Received:

28 May 2019

Accepted:

25 June 2019
Abstract

Epidemiological studies revealed that the pattern of age onset of breast cancer in the Middle East region differ from those in Caucasians. Therefore, genomic data for ESR2 (ER-ß) is of the value in the clinical setting for that ethnic group and the aim of the current investigation is investigated whether polymorphisms in the ER- $\beta$ gene are associated with breast cancer risk among Iranian women. The coding sequence in Exon 7 at ESR2 gene was looking for any variation among the Iranian breast cancer women by SSCP-PCR method.

In codon 392 of exon 7, showed a silent SNP (silent single nucleotide polymorphism). The frequency of allele $\mathbf{G}$ in codon 392 (CTC $\rightarrow$ CTG was found only in cases $(5.7 \%)$. We also found that allele $G$ in codon 392 (C1176G) had direct association with development of lymph node metastasis in breast cancer.

The current results suggest that ESR2 SNP in exon 7, codon 392 is associated with various aspects of breast cancer in Iran. ESR2 gene structure determination, in presurgical evaluation, might be a useful marker in predicting familial breast cancer and metastasis in $L N$.

Keywords: breast cancer, estrogen receptor- $\beta$ (ESR2), polymorphism, metastases, PCR-SSCP. 


\section{INTRODUCTION}

Breast cancer is the second cause of women death from cancer in the world. The geographical variations in not only in incidence of mortality causes by breast cancer but also in breast cancer development suggest that the environmental factors are of more importance than genetic factors [1]. For example, in Iran the average age of onset of breast cancer is 10 years younger than in Western countries [2], [3].

However, only $30 \%$ of all breast cancers are familial [4], suggesting that might unknown genes act in modification of breast cancer risk. It is still unclear which unknown genes and which biochemical pathways are involved for breast cancer incidence or progression.

\section{LITERATURE REVIEW}

Many studies revealed that Estrogen is very important in breast cancer development, while women with menarche at earlier age or menopause with later age can be associated with increasing breast cancer risk [5]-\{7].

However, many evidence showed that polymorphisms in both ESR1 and ESR2 genes were strongly associated with familial breast cancer.[8] and lymph node (LN) metastasis [8]-[12]. At this time there is a little information about ESR2 gene expression and variants frequencies in breast cancer. Thus, in this study we tried to identify gene variants in exon 7 of estrogen receptor $\beta$ gene (ESR2), and its correlation between gene polymorphisms and some clinical characteristics among breast cancer women in Iran

\section{METHODS AND MATERIALS}

\section{Study population}

This research was a case-control study from April 2014 to January 2018 in Tehran, Iran. The breast cancer patients were newly diagnosed in the Imam Khomeini Hospital Complex (n $=150$; median age $47.49 \pm 11.43$ years old). The control group, healthy women with any history of breast cancer and any other neoplastic diseases, and with no history of breast cancer ( $\mathrm{n}=147$; median age $40.75 \pm 10.54$ years). After the hospital ethics committee permission, patients were asked for written informed consent and signed before to participate in this study.

\section{Study population}

The demographical data with selected risk factors such as; menarche onset age, menopause onset age, first degree family with breast cancer and lymph node metastases. For screening for ESR2 polymorphisms by SSCP-PCR methods we used the EDTA peripheral blood.

The genomic DNA was extract by DNGTM-Plus extraction solution kit (Cinnagen Inc, Tehran, Iran). For each PCR we used 50ng genomic DNA and related primers which designed by Primer3 version 0.5.0 software.

Exon 7 F 5' GATGAGGgGAAATGCGTAGA 3' R 5' GGCCCAGCTGTGTGATTACT 3' $156 \mathrm{bp}$

The 30 cycles of PCR were done as follow: at $95^{\circ} \mathrm{C}$ for 30 ', at $58^{\circ} \mathrm{C}$ for $35^{\prime \prime}$, and at $72^{\circ} \mathrm{C}$ for 40 ', followed by electrophoresis running in $13 \%$ polyacrylamide gel, with 250 voltage and 18 hours at $16^{\circ} \mathrm{C}$. The DNA on gel was stained with0.1\% silver nitrate. Then the shifted pattern bands on gel were extracted using DNA Extraction Kit, from Fermentas Co. \# K0153 from Germany, and sequenced directly by Applied Biosystem Kit, Microgen Co. US, ABI 3130XL sequencer.

Purification of DNA products were done using PCR purification Kit protocol (QIA quick) (50). 


\section{Statistical analysis}

In order to find theinfluence of SNPs on breast cancer risk and features we used the $\chi^{2}$ test. Using SPSS software version 20 then for calculating odd ratios with 95\% CIs (confidence intervals) for examining the effects of selected risk factors in breast cancer .The results were considered as statistically significant when $\mathrm{P}$ was greater 0.05 .

\section{RESULTS}

The ESR2 gene is located on Chromosome 14, with 8 exons. The encoding region exon 7 of the ESR2 gene was examined for any variant region using SSCP-PCR. Then we found a SNP of rs1256054 in codon 392 where codes for Leucine amino acid (dbSNP128) in which nucleotide $\mathrm{C}$ is converted to $\mathrm{G}$ (CTC to CTG) [13] which was presented in the case group, with CG heterozygote $8.7 \%$ and GG homozygote $1.3 \%$, while $\mathrm{CC}$ with $90.0 \%$.( $\mathrm{P}=0.029)$.

The $\mathrm{G}$ allelic frequency was higher in cases with Onset age for menarche, $</=12$ years old with $9.2 \%$ than $>12$ years old with $3.3 \%$.

The $\mathrm{G}$ allelic frequency was higher in the cases with breast cancer history with $36.8 \%$ than in those without a family history $1.1 \%$, a $35.7 \%$, differences. While the allelic frequencies of allele $\mathrm{C}$ is lower in patients without family history $(\mathrm{P}=0.001)$. However, the allelic frequencies of allele $\mathrm{G}$ was significantly higher in $\mathrm{LN}$ metastases cases with $23.9 \%$ in compare with those without $\mathrm{LN}$ metastases (2.4\%). Moreover, the $\mathrm{C}$ allelic frequency was lower in $\mathrm{LN}$ metastases cases with $67.1 \%$ than cases without LN metastases with $97.6 \%$ (Table 1).

The estimated risk was higher in cases without family history of breast cancer than individuals with breast cancer history ( $94.8 \%$ and $5.2 \%$ respectively) who were CC normal homozygote. In compare with CG heterozygote, for codon 392 polymorphism, with threefold higher frequency for individuals with family history than individuals without family history of breast cancer (76.9\% and $23.1 \%$ respectively) (and with GG genotype, all were presented in the cases with family history.

The risk for developing breast cancer was lower for individuals without LN metastases who were CC, normal, in codon 392 (89.6\% and 10.4\%), but in corresponding CG heterozygote genotype the risk was higher for $\mathrm{LN}$ metastases cases (53.8\%) than for individuals without $\mathrm{LN}$ metastases (46.2\%) (OR 0.099, 95\% CI 0.029-0.337). Although, GG homozygote, in codon 392 individuals, all were only within the patients with LN metastases.

\section{DISCUSSION}

The SNP of estrogen receptor $\beta$ was only presented in cancer patients, $8.7 \%$ in CG heterozygote genotype and $1.3 \%$ in GG homozygote genotype in exon 7 in Iranian cancer patients. Among German population Five SNPs in ER- $\beta$ gene have been identified [14], however, only rs1256049, showed an association with anorexia nervosa. This SNP had shown colorations with ovulatory dysfunction in a Chinese and Brazilian [15], [16]. Moreover, a CA nucleotide repeats in ESR2 gene revealed association with bone density in Japanese. [17]. The Shanghai research center reported an SNP at exon 7 wich related. to the increase risk of breast cancer [18], and suggested it plays as an enhancer slicing [19], [20]. Although, not all polymorphisms in ERs associated with increasing the risk of breast cancer development, such as PvuII and XbaI polymorphisms [21], [22].

The allele G frequency was higher in LN cases than cases without LN metastases (Table 1). Moreover, the estimated risk showed higher in cases with familial breast cancer than those without family history ( $94.8 \%$ and $5.2 \%$ respectively) who were CC normal homozygote. In compare with CG heterozygote, for codon 392 polymorphism, with threefold higher frequency for individuals with family history than individuals without family history (76.9\% and $23.1 \%$ respectively) and with GG genotype in the cases with family history.

In CG heterozygote, the risk was higher for LN metastasis cases (53.8\%) than for individuals without LN metastases (46.2\%) (OR 0.099, 95\% CI 0.029-0.337), in compare with CC normal individuals. Although was less likely in the cases $(\mathrm{OR}<1)$. (Table 2). 
Our results revealed that codon 392 polymorphism in ESR2 is significantly different in case and control groups $(10.1 \%$ and $0.0 \%$ respectively) in compare with only one similar study in China population (17), it showed same frequencies in codon 392 polymorphism among case and control groups (93.5\% and $94.7 \%$ respectively). Taking these results together, codon 392 SNP as conferring the increasing risk of developing breast cancer. We also noted that higher the frequency of allele G, the greater to have LN metastasis in Iranian breast cancer women.

\subsection{Figures and Tables}

Table 1. Genotypic and allelic frequencies of ESR2, exon 7, codon 392: cases / control and selected risk factors

\begin{tabular}{|c|c|c|c|c|c|c|}
\hline \multirow{2}{*}{\multicolumn{2}{|c|}{$\begin{array}{l}\text { Codon } 392 \\
\text { Characteristic }\end{array}$}} & \multicolumn{3}{|c|}{ ER- $\beta$ genotypes } & \multicolumn{2}{|l|}{ ER- $\beta$ Alleles } \\
\hline & & $\mathbf{C C}$ & CG & GG & $\mathbf{C}$ & $\mathbf{G}$ \\
\hline \multicolumn{7}{|c|}{ Breast cancer } \\
\hline Case & $(n=150)$ & $135(90.0 \%)$ & $13(8.7 \%)$ & $2(1.3 \%)$ & $283(94.3 \%)$ & $17(5.7 \%)$ \\
\hline Control & $(n=147)$ & $147(100 \%)$ & - & - & $294(100 \%)$ & - \\
\hline & & \multicolumn{3}{|c|}{$\chi^{2}=4.769, \quad P=0.029$} & \multicolumn{2}{|l|}{$P=0.001$} \\
\hline \multicolumn{7}{|c|}{ Age at menarche(years) } \\
\hline$</=12$ & $(\mathrm{n}=60)$ & $50(83.3 \%)$ & $9(15.0 \%)$ & $1(1.7 \%)$ & $109(90.8 \%)$ & $11(9.2 \%)$ \\
\hline$>12$ & $(n=90)$ & $85(94.4 \%)$ & $4(4.4 \%)$ & $1(1.2 \%)$ & $174(96.7 \%)$ & $6(3.3 \%)$ \\
\hline & & \multicolumn{3}{|c|}{$\chi^{2}=0.604, \quad P=0.437$} & \multicolumn{2}{|l|}{$P=0.032$} \\
\hline \multicolumn{7}{|c|}{ Family history of breast cancer } \\
\hline $\begin{array}{l}\text { First-degree } \\
\text { family } \\
\text { affected }\end{array}$ & $(n=19)$ & $7(36.8 \%)$ & $10(52.6 \%)$ & $2(10.6 \%)$ & $24(63.2 \%)$ & $14(36.8 \%)$ \\
\hline \multirow[t]{2}{*}{ Not affected } & $(n=131)$ & $128(97.7 \%)$ & $3(2.3 \%)$ & - & $259(98.9 \%)$ & $3(1.1 \%)$ \\
\hline & & \multicolumn{3}{|c|}{$\chi^{2}=27.645, \quad P=0.001$} & \multicolumn{2}{|l|}{$P=0.001$} \\
\hline \multicolumn{7}{|c|}{ Lymph node metastases } \\
\hline Yes & $(n=23)$ & $14(60.9 \%)$ & $7(30.4 \%)$ & $2(8.7 \%)$ & $35(76.1 \%)$ & $11(23.9 \%)$ \\
\hline No & $(n=127)$ & $121(95.3 \%)$ & $6(4.7 \%)$ & - & $248(97.6 \%)$ & $6(2.4 \%)$ \\
\hline & & \multicolumn{3}{|c|}{$\chi^{2}=17.314, \quad P=0.001$} & \multicolumn{2}{|l|}{$P=0.001$} \\
\hline \multicolumn{7}{|c|}{ ER expression in breast cancer tissue } \\
\hline Positive & $(\mathrm{n}=40)$ & $32(80.0 \%)$ & $6(15.0 \%)$ & $2(5.0 \%)$ & $70(87.5 \%)$ & $10(12.5 \%)$ \\
\hline Negative & $(n=92)$ & $87(94.6 \%)$ & $5(5.4 \%)$ & - & $179(97.3 \%)$ & $5(2.7 \%)$ \\
\hline Not studied & $(n=18)$ & $16(88.9 \%)$ & $2(11.1 \%)$ & - & $34(94.4 \%)$ & $2(5.6 \%)$ \\
\hline & & \multicolumn{3}{|c|}{$\chi^{2}=4.779, \quad P=0.028$} & \multicolumn{2}{|l|}{$P=0.023$} \\
\hline
\end{tabular}


Table 2. Estimated risk for selected characteristic and risk factors with ESR2, exon 7, codon 392 in different genotypes

\begin{tabular}{|c|c|c|c|c|}
\hline $\begin{array}{l}\text { Breast cancer } \\
\text { Genotype }\end{array}$ & $\begin{array}{l}\text { Yes } \\
n=150\end{array}$ & $\begin{array}{l}\text { No } \\
n=147\end{array}$ & $P$ value & OR $(95 \% \mathrm{CI})$ \\
\hline Normal CC & $135(47.9 \%)$ & $147(52.1 \%)$ & \multirow{3}{*}{0.029} & 1.0 (reference) \\
\hline Heterozygote CG & $13(100 \%)$ & - & & - \\
\hline Homozygote GG & $2(100 \%)$ & - & & - \\
\hline $\begin{array}{l}\text { Age at menarche (years) } \\
\text { Genotype }\end{array}$ & $\begin{array}{l}</=12 \\
\mathrm{n}=60\end{array}$ & $\begin{array}{l}>12 \\
n=90\end{array}$ & $P$ value & OR $(95 \% \mathrm{CI})$ \\
\hline Normal CC & $50(37.0 \%)$ & $85(63 \%)$ & \multirow{3}{*}{0.437} & 1.0 (reference) \\
\hline Heterozygote CG & $9(69.2 \%)$ & $4(30.8 \%)$ & & $\begin{array}{l}0.261(0.077- \\
0.893)\end{array}$ \\
\hline Homozygote GG & $1(50 \%)$ & $1(50 \%)$ & & $\begin{array}{l}0.588(0.036- \\
9.613)\end{array}$ \\
\hline $\begin{array}{l}\text { First- degree } \\
\text { family history } \\
\text { of breast cancer } \\
\text { Genotype }\end{array}$ & $\begin{array}{l}\text { Affected } \\
n=19\end{array}$ & $\begin{array}{l}\text { Not affected } \\
n=131\end{array}$ & $P$ value & OR $(95 \%$ CI $)$ \\
\hline Normal CC & $7(5.2 \%)$ & $128(94.8 \%)$ & \multirow{3}{*}{0.001} & $1.0($ reference $)$ \\
\hline Heterozygote CG & $10(76.9 \%)$ & $3(23.1 \%)$ & & $\begin{array}{l}0.016(0.004- \\
0.073)\end{array}$ \\
\hline Homozygote GG & $2(100 \%)$ & - & & - \\
\hline $\begin{array}{l}\text { Lymph } \\
\text { node metastases } \\
\text { Genotype }\end{array}$ & $\begin{array}{l}\text { Yes } \\
n=23\end{array}$ & $\begin{array}{l}\text { No } \\
n=127\end{array}$ & $P$ value & OR $(95 \%$ CI $)$ \\
\hline Normal CC & $14(10.4 \%)$ & $121(89.6 \%)$ & \multirow{3}{*}{0.001} & $1.0($ reference $)$ \\
\hline Heterozygote CG & $7(53.8 \%)$ & $6(46.2 \%)$ & & $\begin{array}{l}0.099(0.029- \\
0.337)\end{array}$ \\
\hline Homozygote GG & $2(100 \%)$ & - & & - \\
\hline
\end{tabular}

\section{CONCLUSION}

This was the first study in estrogen receptor gene polymorphism and breast cancer risk in breast cancer. Our data suggested that ESR2 polymorphism is correlated with various aspects of breast cancer in Iran. In ESR2 genotype, the higher allelic frequency of allele G in 392 codon the more likelihood to develop familial breast cancer and lymph node metastasis in Iranian breast cancer. Therefore it represents a candidate marker for predicting for familial breast cancer and LN metastasis.

The Tehran University of Medical Sciences \& Health services, Research Deputy Grants supported this research.

\section{REFERENCE}

[1] K. McPherson, C. Steel, and J. M. Dixon, "Breast cancer-epidemiology, risk factors, and genetics," Bmj, vol. 321, no. 7261, pp. 624-628, 2000.

[2] I. Harirchi, M. Ebrahimi, N. Zamani, S. Jarvandi, and A. Montazeri, "Breast cancer in Iran: a review of 903 case records," Public health, vol. 114, no. 2, pp. 143-145, 2000.

[3] S. M. Mousavi et al., "Breast cancer in Iran: an epidemiological review," The breast journal, vol. 13, no. 4, pp. 383-391, 2007.

[4] B. Newman, H. Mu, L. M. Butler, R. C. Millikan, P. G. Moorman, and M.-C. King, "Frequency of breast 
cancer attributable to BRCA1 in a population-based series of American women," Jama, vol. 279, no. 12, pp. 915-921, 1998

[5] C. B. Tempfer, C. Schneeberger, and J. C. Huber, "Applications of polymorphisms and pharmacogenomics in obstetrics and gynecology," Pharmacogenomics, vol. 5, no. 1, pp. 57-65, 2004.

[6] S. C. Lymberis, P. K. Parhar, E. Katsoulakis, and S. C. Formenti, "Pharmacogenomics and breast cancer," Pharmacogenomics, vol. 5, no. 1, pp. 31-55, 2004

[7] K. I. Bland and E. M. Copeland III, "The breast: comprehensive management of benign and malignant disorders 3rd. ed," St. Louis: Elsevier, 2004.

[8] N. Roodi et al., "Estrogen receptor gene analysis in estrogen receptor-positive and receptor-negative primary breast cancer," JNCI: Journal of the National Cancer Institute, vol. 87, no. 6, pp. 446-451, 1995.

[9] J. Wang et al., "Estrogen receptor alpha haplotypes and breast cancer risk in older Caucasian women," Breast cancer research and treatment, vol. 106, no. 2, pp. 273-280, 2007.

[10] R. M. Ghali et al., "Differential association of ESR1 and ESR2 gene variants with the risk of breast cancer and associated features: A case-control study," Gene, vol. 651, pp. 194-199, 2018.

[11] S. Chattopadhyay et al., "Genetic polymorphisms of ESR1, ESR2, CYP17A1, and CYP19A1 and the risk of breast cancer: a case control study from North India," Tumor Biology, vol. 35, no. 5, pp. 4517-4527, 2014.

[12] V. Srinivasan et al., "Melatonin, environmental light, and breast cancer," Breast cancer research and treatment, vol. 108, no. 3, pp. 339-350, 2008.

[13] "Ensembl genome browser 97." [Online]. Available: https://asia.ensembl.org/index.html. [Accessed: 05-Jul2019].

[14] K. Rosenkranz et al., "Systematic mutation screening of the estrogen receptor beta gene in probands of different weight extremes: identification of several genetic variants," The Journal of Clinical Endocrinology \& Metabolism, vol. 83, no. 12, p. 4524, 1998.

[15] C. Sundarrajan, W. X. Liao, A. C. Roy, and S. C. Ng, "Association between estrogen receptor- $\beta$ gene polymorphisms and ovulatory dysfunctions in patients with menstrual disorders," The Journal of Clinical Endocrinology \& Metabolism, vol. 86, no. 1, pp. 135-139, 2001.

[16] S. Ogawa et al., "Association of estrogen receptor $\beta$ gene polymorphism with bone mineral density," Biochemical and biophysical research communications, vol. 269, no. 2, pp. 537-541, 2000.

[17] L. M. Rezende, F. A. L. Marson, C. S. P. Lima, and C. S. Bertuzzo, "Variants of estrogen receptor alpha and beta genes modify the severity of sporadic breast cancer," Gene, vol. 608, pp. 73-78, 2017.

[18] S. L. Zheng et al., "Joint effect of estrogen receptor $\beta$ sequence variants and endogenous estrogen exposure on breast cancer risk in Chinese women," Cancer research, vol. 63, no. 22, pp. 7624-7629, 2003.

[19] W. Wu, L. Abraham, J. Ogony, R. Matthews, G. Goldstein, and N. Ercal, "Effects of N-acetylcysteine amide (NACA), a thiol antioxidant on radiation-induced cytotoxicity in Chinese hamster ovary cells," Life sciences, vol. 82, no. 21-22, pp. 1122-1130, 2008.

[20] A. M. G.-Z. Ladd et al., "Estrogen receptor $\alpha$ polymorphisms and postmenopausal breast cancer risk," Breast cancer research and treatment, vol. 107, no. 3, pp. 415-419, 2008.

[21] S. Jahandoost, P. Farhanghian, and S. Abbasi, "The effects of sex protein receptors and sex steroid hormone gene polymorphisms on breast cancer Risk," Journal of the National Medical Association, vol. 109, no. 2, pp. 126-138, 2017.

[22] Y. Du, T. Yan, L. Zhou, W. Yin, and J. Lu, "A single-nucleotide polymorphism of the beta 2-adrenergic receptor gene can predict pathological complete response to taxane-and platinum-based neoadjuvant chemotherapy in breast cancer," Breast Cancer: Targets and Therapy, vol. 10, p. 201, 2018. 